\title{
THE IMPLEMENTATION OF SIMPLE ADDITIVE WEIGHTING METHOD IN THE SELECTION OF REHABILITATION FUND RECIPIENTS FOR UNINHABITABLE HOME
}

\author{
Dwi Krisbiantoro \\ Program Studi Sistem Informasi \\ STMIK Amikom Purwokerto \\ Email: dwikris@amikompurwokerto.ac.id \\ Wiga Maulana Baihaqi \\ Program Studi Teknologi Informasi \\ STMIK Amikom Purwokerto \\ Email: wiga@amikompurwokerto.ac.id
}

\begin{abstract}
The rehabilitation program is one of the programs given to people who have homes that are not habitable. They are usually from poor families with low economic income. In this program, the family will receive funds to rehabilitate their home. However, as long as the program is running, various problems have been encountered, including those who received fund sometimes received back the fund for rehabilitation funds. This is of course not in accordance with regulations that only allow applicants to receive the fund once. Based on this problem, a decision support system was made to select potential recipients of rehabilitation funds for uninhabitable house. By using the SAW method which is based on the value of criteria and preference weights, an appropriate assessment and ranking can be obtained after going through the selection process of assessing the weight of each attribute. The support for the selection decision for receiving uninhabitable rehabilitation fund was generated in this study. Decision making to determine beneficiaries was facilitated by the existence of a decision support system that was submitted, so that the fund provided was targeted at those entitled to receive uninhabitable rehabilitation fund.
\end{abstract}

Keywords: rehabilitation of uninhabitable homes; decision support systems; SAW.

\section{INTRODUCTION}

Regional and central governments have a fundamental problem that must be considered, namely poverty. The measure of the level of welfare of a region is measured by the poverty level of its citizens in an area, so that poverty is used as a development priority. The regional and central government has allocated a budget to make various poverty programs. As the Regulation made by the Regional Government of Purbalingga Regency, namely Article 22 paragraph 1 Number 9 of 2015 concerning the Acceleration of Poverty Reduction. Based on these regulations, the government in the Purbalingga District has arranged a program related to grants to rehabilitate uninhabitable homes. The program is called Social Assistance for the Rehabilitation of Unqualified Houses, which aims to meet the needs of healthy and naturally livable boards, especially for poor or poor families [1].

Poor families whose board needs are not able to be fulfilled and the house occupied is included in the criteria of unfit for habitation deserve to receive the Inhabitable Rehabilitation Program (RRTLH) that has been designed by the regional and central government. RRTLH is aimed at dealing with poverty, especially in order to fulfill a decent home for poor families. Prospective recipients of assistance for rehabilitating uninhabitable homes must meet certain criteria as a condition of recipients of assistance, there are certain criteria for prospective recipients so that the process of granting assistance is targeted to eligible residents. The government has determined the flow in which the channel is related to the selection process in providing aid funds to rehabilitate uninhabitable homes for poor families. Of course this process must follow a predetermined mechanism.

Variables used to determine a house that is not suitable for habitation are the walls of the house, the roof of the house, the floor of the house, the ventilation of the house, the source of water, the land SHM and the status of receiving assistance. The government does not provide assistance to all residents who are eligible for assistance, it is the quota that limits the number of recipients of rehabilitation funds. However, the selection process faced some difficulties such as in processing the data requiring accuracy, so as to allow duplicate data to occur as well as the occurrence of errors in determining citizen who should take precedence. Giving aid funds is not on target because residents who should receive assistance but do not accept, and who should not receive but in fact receive assistance. Even rehabilitation funds that have been 
received by residents can be received twice by the same residents. So that in determining the right citizen to receive uninhabitable housing rehabilitation funds, a decision support system is needed.

Research related to the design of a decision support system, the MADM-Tool application has been made by [2]. The SAW and TOPSIS methods are used to test the sensitivity of the MADM model. The relevance of the SAW and TOPSIS methods in dealing with certain MADM problems can be determined by the application designed. The SAW method states that the relevant methods solve a particular MADM case or problem. These results are the results of sensitivity testing using the MADM-Tool; the SAW method gets a percentage of $8 \%$ while TOPSIS gets a percentage of $4 \%$.

Several previous references or studies were used in this study, the SAW and Weighted Product (WP) methods were used by [3] to provide recommendations for RASTRA recipients. With the presence of RASTRA, the community can be helped to meet rice needs. The decision support system application using the SAW method and desktop-based WP was produced in this study. The SAW method produced a preference value compared to the SAW method, because the same alternative preference value can be minimized by the SAW method, the results were generated based on the results of the test. This is indicated by the SAW method producing 13 ranks while WP was 10 ranks when viewed from alternative ranking.

Furthermore, the SAW method and geographic information system were utilized by [4] to assist the Surakarta city government in determining the location of the evacuation of floods. With the existence of this system, early preparation can be detected by the people of Surakarta when flood occurred the residential areas of the community. Internal and external barriers were also experienced by the Klungkung sub-district to select residents who received village assistance, for example there was no decision support system that could assist in determining village beneficiaries. So [5] conducted a study to build a decision support system using a website-based SAW method. The criteria used to assess citizens who deserved to receive village assistance were physical homes, income, education, and natural conditions. In developing the system, researchers used the method of waterfall development system. [6] conducted research at Srowot Village regarding the process of providing subsidized rice to poor people. The inappropriate target was the main problem in the process of providing subsidized rice. The method of waterfall system and the SAW method was used to develop a decision support system to assist the government of Srowot Village in providing subsidized rice to poor residents. The resulting system was tested by the black-box method.

The advantages possessed by the SAW method namely it can produce an assessment process quickly, because in the process the SAW method must first determine the value of preference criteria and weights, besides the best alternative of several available alternatives can be selected by the SAW method because of the process of determining weight values for each attribute before the alternative ranking process [7].

From the above problems, the researchers tried to create a decision support system that could assist in assisting officers in the selection of recipients for rehabilitating uninhabitable homes. For this reason, the researcher is interested in taking the title "The Implementation of Simple Additive Weighting Method in the Selection of Rehabilitation Fund Recipients for Uninhabitable Home" with a case study of Karangkemiri Village, Kemangkon District, Purbalingga Regency.

\section{METODOLOGI PENELITIAN}

\subsection{Material}

The research material used in this study is the house data considered as an uninhabitable house to receive rehabilitation fund from the government of Karangkemiri village, Pekuncen sub-district, Banyumas regency.

\subsection{Simple Additive Weighting Method (SAW)}

Decisions are activities or actions to choose one alternative from several alternatives taken as a solution to the problem [8][9][10]. The types of decisions taken to solve a problem can be seen from the type of structure, such as: (1) Structured Decisions are decisions made repeatedly and are routine. The decision making procedure is very clear. (2) Semi-structured decisions are decisions that have two traits. Some decisions can be handled by the computer and others must be done by the decision maker. (3) Unstructured Decisions, it is a complicated handling decision because it does not happen repeatedly or does not always occur.

Decisions require experience and external sources. Decision making includes four interconnected and sequential stages, including: (1) Intelligent, Is a stage in tracking and detecting problems. The data is then processed and tested so that problems can be identified. (2) Design, After the problem is found, then a solution is sought or an alternative action is taken, then tested whether the solution is feasible or not. (3) 
Option, The selection process by using various alternative actions includes searching, evaluating, and recommending solutions that are in accordance with the designed model, namely the specific value for the outcome variable on the chosen alternative [11][12][13]. (4) Implementation, Is the stage of decision making. A set of planned actions needs to be arranged to monitor the results of decisions that are appropriate to the needs.

The weighted sum method is another name for the SAW method. A distinctive feature of the SAW method is to calculate the number of weighted performance ratings in each alternative on all attributes. The process of normalizing the decision matrix $(\mathrm{X})$ to a scale comparable to all alternative rankings is required by the SAW method [14][15]. Equation 1 shows the normalization equation of the SAW method.

$R_{i j}=\left\{\begin{array}{l}\frac{X_{i j}}{\operatorname{Max} X_{i j}} \\ \frac{\operatorname{Min} X_{i j}}{X_{i j}}\end{array}\right.$

Explanation :

$\mathrm{R}_{\mathrm{ij}}=$ Normalized performance value

Maxij $=$ The largest value of each row and column

Minij $=$ The smallest value of each row and column

$\mathrm{Xij}=$ The rows and columns of the maximum matrix are chosen as the best alternates (Ai) as solutions.

With Rij the normalized performance rating of the alternative $\mathrm{Ai}$ in the $\mathrm{Cj}$ attribute; $\mathrm{i}=1,2, \ldots \mathrm{m}$ and $\mathrm{j}=$ $1,2, \ldots, \mathrm{n}$.

$V_{i}=\sum_{j=1}^{n} W_{j} R_{i j}$

A larger $\mathrm{Vi}$ value indicates that the alternative $\mathrm{Ai}$ is more chosen.

Explanation :

$\mathrm{Vi}=$ The final value of the alternative

$\mathrm{Wi}=$ predetermined weight

Rij = Normalization of the matrix

The chosen alternative is indicated by a greater value. The problem of selection in a multi-process decision-making system is recommended to be solved using the Simple Additive Weighting (SAW) method. SAW method is a method that is widely used in decision making that has many attributes. Simple Additive Weight (SAW) Method According to Fishburn and MacCrimmon in [16] have steps in resolving decision-making cases, these steps are as follows: (1) $\mathrm{Ci}$ is a symbol for decision support criteria. (2) Match values for each alternative on each criterion. (3) Decision matrix based on criteria (Ci). (4) Normalization of matrices based on equations according to the type of attribute to obtain a normalized matrix R

\section{RESULTS AND DISCUSSION}

\subsection{Determination of Criteria}

The application of Simple Additive Weighting (SAW) method in decision support systems requires criteria and weighting values and several alternatives that will be calculated in the rating and assessment process in determining the level of salary increase, as an experiment there are 5 alternative data samples that will get rehabilitation assistance. The following are data from 5 alternative data samples used.

Table 1. Alternative data

\begin{tabular}{cl}
\hline Alternative & Name \\
\hline A 01 & Kaka 1 \\
A 02 & Kaka 2 \\
A 03 & Kaka 3 \\
A 04 & Kaka 4 \\
A 05 & Kaka 5 \\
\hline
\end{tabular}


The first step that must be taken in calculating the house rehabilitation assistance in accordance with the above case uses the Simple Additive Weighting (SAW) method, which is determining performancebased criteria and fuzzy numbers in SAW for the weight values to be used for assessment. Table 2 shows a list of criteria and the weight of each criterion in this study. Table 3-9 shows more detailed criteria.

Table 2. Weight criteria and values

\begin{tabular}{lll}
\hline \multicolumn{1}{c}{ Criteria } & Value & $\begin{array}{c}\text { Weight } \\
(\boldsymbol{W})\end{array}$ \\
\hline Wall C1) & $25 \%$ & 0,25 \\
Roof ( (C2) & $20 \%$ & 0,20 \\
Floor (C3) & $15 \%$ & 0,15 \\
Ventilation (C4) & $10 \%$ & 0,10 \\
Springs (C5) & $10 \%$ & 0,10 \\
Land Certification (C6) & $10 \%$ & 0,10 \\
Status of Acceptance of & $10 \%$ & 0,10 \\
Assistance (C7) & & \\
\hline
\end{tabular}

Table 3. Criteria for walls

\begin{tabular}{lllc}
\hline & Wall $(\boldsymbol{C 1})$ & Weight & Value \\
\hline Wall & Good & 1 \\
Wall combined & by & Fair & 2 \\
bamboo or wood & & Bad & 3 \\
Bamboo or wood & & 3 \\
\hline
\end{tabular}

Table 4. Roof criteria

\begin{tabular}{lcc}
\hline \multicolumn{1}{c}{ Roof $(\boldsymbol{C 2})$} & Weight & Value \\
\hline Good condition & Good & 1 \\
Bad condition & Bad & 2 \\
\hline
\end{tabular}

Table 5. Floor criteria

\begin{tabular}{lcc}
\hline \multicolumn{1}{c}{ Floor $(\boldsymbol{C 3})$} & Weight & Value \\
\hline $\begin{array}{l}\text { Cement with good } \\
\text { condition }\end{array}$ & Good & 1 \\
$\begin{array}{l}\text { Cement with bad } \\
\text { condition }\end{array}$ & Fair & 2 \\
Soil or wood & Bad & 3 \\
\hline
\end{tabular}

Table 6. Ventilation criteria

\begin{tabular}{lcc}
\hline \multicolumn{1}{c}{ Ventilation $($ C4) } & Weight & Value \\
\hline Good Ventilation & Good & 1 \\
Bad Ventilation & Bad & 2 \\
\hline
\end{tabular}

Table 7. Springs criteria

\begin{tabular}{ccc}
\hline Springs (C5) & Weight & Value \\
\hline Well & Good & 1 \\
River & Bad & 2 \\
\hline
\end{tabular}

Table 8. Criteria for land certificate

\begin{tabular}{ccc}
\hline Land Certificate (C6) & Weight & Value \\
\hline Private & Good & 2 \\
Public & Bad & 1 \\
\hline
\end{tabular}


Table 9. Criteria for RRTLH assistance

\begin{tabular}{lcc}
\hline Assistance RRTLH $($ C7) & Weight & Value \\
\hline Received & Good & 2 \\
Not received yet & Bad & 1 \\
\hline
\end{tabular}

\subsection{Use of each Criterion to Determine the Suitability Rating for each Alternative}

The steps taken in determining the compatibility rating are entering the value of each criterion into the match rating table that has been adjusted to the value from the criteria table. Table 10 shows a compatibility rating.

Table 10. Compatibility rating

\begin{tabular}{llllllll}
\hline \multirow{2}{*}{ Alternative } & \multicolumn{7}{c}{ Criteria } \\
\cline { 2 - 8 } & C1 & C2 & C3 & C4 & C5 & C6 & C7 \\
\hline A 01 & 2 & 2 & 2 & 1 & 2 & 1 & 2 \\
A 02 & 1 & 1 & 1 & 2 & 1 & 2 & 2 \\
A 03 & 3 & 2 & 3 & 2 & 1 & 1 & 1 \\
A 04 & 3 & 2 & 3 & 1 & 1 & 2 & 1 \\
A 05 & 2 & 2 & 3 & 2 & 1 & 1 & 2 \\
\hline
\end{tabular}

\subsection{Creating a Decision Matrix Based on Criteria}

Table 10 (compatibility rating) is used to form a decision matrix. The compatibility rating matrix can be seen as follows:

$$
X=\left[\begin{array}{lllllll}
2 & 2 & 2 & 1 & 2 & 1 & 2 \\
1 & 1 & 1 & 2 & 1 & 2 & 2 \\
3 & 2 & 3 & 2 & 1 & 1 & 1 \\
3 & 2 & 3 & 1 & 1 & 2 & 1 \\
2 & 2 & 3 & 2 & 1 & 1 & 2
\end{array}\right]
$$

\subsection{Normalization of Matrices}

Normalization Matrices are based on equations that are adjusted to the type of attribute (gain attribute or cost attribute) so that the normalized matrix R. obtains detailed calculations on each component are as follows:

$$
\begin{aligned}
& \mathrm{r} 11=\frac{2}{\operatorname{MAX}\{2 ; 1 ; 3 ; 3 ; 2\}}=2 / 3=0,6667 \\
& \mathrm{r} 12=\frac{2}{\operatorname{MAX}\{2 ; 1 ; 2 ; 2 ; 2\}}=2 / 2=1 \\
& \mathrm{r} 13=\frac{2}{\operatorname{MAX}\{2 ; 1 ; 3 ; 3 ; 3]}=2 / 3=0,6667 \\
& \mathrm{r} 14=\frac{1}{\operatorname{MAX}\{1 ; 2 ; 2 ; 1 ; 2\}}=1 / 2=0,5 \\
& \mathrm{r} 15=\frac{2}{\operatorname{MAX}\{2 ; 1 ; 1 ; 1 ; 1\}}=2 / 2=1 \\
& \mathrm{r} 16=\frac{1}{\operatorname{MAX}\{1 ; 2 ; 1 ; 2 ; 1\}}=1 / 2=0,5 \\
& \mathrm{r} 17=\frac{2}{\operatorname{MAX}\{2 ; 2 ; 1 ; 1 ; 2\}}=2 / 2=1 \\
& \mathrm{r} 21=\frac{1}{\operatorname{MAX}\{2 ; 1 ; 3 ; 3 ; 2\}}=1 / 3=0,3333
\end{aligned}
$$




$$
\begin{aligned}
& \mathrm{r} 22=\frac{1}{\operatorname{MAX}\{2 ; 1 ; 2 ; 2 ; 2\}}=1 / 2=0.5 \\
& \mathrm{r} 23=\frac{1}{\operatorname{MAX}\{2 ; 1 ; 3 ; 3 ; 3\}}=1 / 3=0,3333 \\
& \mathrm{r} 24=\frac{2}{\operatorname{MAAX}\{1 ; 2 ; 2 ; 1 ; 2\}}=2 / 2=1 \\
& \mathrm{r} 25=\frac{1}{\operatorname{MAX}\{2 ; 1 ; 1 ; 1 ; 1\}}=1 / 2=0,5 \\
& \mathrm{r} 26=\frac{2}{\operatorname{MAX}\{1 ; 2 ; 1 ; 2 ; 1\}}=2 / 2=1 \\
& \mathrm{r} 27=\frac{2}{\operatorname{MAX}\{2 ; 2 ; 1 ; 1 ; 2\}}=2 / 2=1 \\
& \mathrm{r} 31=\frac{3}{\operatorname{MAX}\{2 ; 1 ; 3 ; 3 ; 2\}}=3 / 3=1 \\
& \mathrm{r} 32=\frac{2}{\operatorname{MAX}\{2 ; 1 ; 2 ; 2 ; 2\}}=2 / 2=1 \\
& \mathrm{r} 33=\frac{3}{\operatorname{MAX}\{2 ; 1 ; 3 ; 3 ; 3\}}=3 / 3=1 \\
& \mathrm{r} 34=\frac{2}{\operatorname{MAX}\{1 ; 2 ; 2 ; 1 ; 2\}}=2 / 2=1 \\
& \mathrm{r} 35=\frac{1}{\operatorname{MAX}\{2 ; 1 ; 1 ; 1 ; 1\}}=1 / 2=0,5 \\
& \mathrm{r} 36=\frac{1}{\operatorname{MAX}\{1 ; 2 ; 1 ; 2 ; 1\}}=1 / 2=0,5 \\
& \mathrm{r} 37=\frac{1}{\operatorname{MAX}\{2 ; 2 ; 1 ; 1 ; 2\}}=1 / 2=0,5 \\
& \mathrm{r} 41=\frac{3}{\operatorname{MAX}\{2 ; 1 ; 3 ; 3 ; 2\}}=3 / 3=1 \\
& \mathrm{r} 42=\frac{2}{\operatorname{MAX}\{2 ; 1 ; 2 ; 2 ; 2\}}=2 / 2=1 \\
& \mathrm{r} 43=\frac{3}{\operatorname{MAX}\{2 ; 1 ; 3 ; 3 ; 3\}}=3 / 3=1 \\
& \mathrm{r} 44=\frac{1}{\operatorname{MAX}\{1 ; 2 ; 2 ; 1 ; 2\}}=1 / 2=0,5 \\
& \mathrm{r} 45=\frac{1}{\operatorname{MAX}\{2 ; 1 ; 1 ; 1 ; 1\}}=1 / 2=0,5 \\
& \mathrm{r} 46=\frac{2}{\operatorname{MAX}\{1 ; 2 ; 1 ; 2 ; 1\}}=2 / 2=1 \\
& \mathrm{r} 47=\frac{1}{\operatorname{MAX}\{2 ; 2 ; 1 ; 1 ; 2\}}=1 / 2=0,5 \\
& \mathrm{r} 51=\frac{2}{\operatorname{MAX}\{2 ; 1 ; 3 ; 3 ; 2\}}=2 / 3=0,6667 \\
& \mathrm{r} 52=\frac{2}{\operatorname{MAX}\{2 ; 1 ; 2 ; 2 ; 2\}}=2 / 2=1 \\
& \mathrm{r} 53=\frac{3}{\operatorname{MAX}\{2 ; 1 ; 3 ; 3 ; 3\}}=3 / 3=1 \\
& \mathrm{r} 54=\frac{2}{\operatorname{MAX}\{1 ; 2 ; 2 ; 1 ; 2\}}=2 / 2=1 \\
& \mathrm{r} 55=\frac{1}{\operatorname{MAX}\{2 ; 1 ; 1 ; 1 ; 1\}}=1 / 2=0,5 \\
& \mathrm{r} 56=\frac{1}{\operatorname{MAX}\{1 ; 2 ; 1 ; 2 ; 1\}}=1 / 2=0.5 \\
& \mathrm{r} 57=\frac{2}{\operatorname{MAX}\{2 ; 2 ; 1 ; 1 ; 2\}}=2 / 2=1
\end{aligned}
$$


From the information available, then a matrix results from normalization $\mathrm{R}$ are made from the $\mathrm{X}$ matrix as follows:

$\mathrm{R}=\left[\begin{array}{ccccccc}0,667 & 1 & 0,667 & 0,5 & 1 & 0,5 & 1 \\ 0,333 & 0,5 & 0,333 & 1 & 0,5 & 1 & 1 \\ 1 & 1 & 1 & 1 & 0,5 & 0,5 & 0,5 \\ 1 & 1 & 1 & 0,5 & 0,5 & 1 & 0,5 \\ 0,667 & 1 & 1 & 1 & 0,5 & 0,5 & 1\end{array}\right]$

\subsection{Determining Ranking}

V1 through V5 are determined to find the value of each applicant who will receive assistance for rehabilitation of uninhabitable homes. In order to get a ranking value (V), then calculate per alternative value with the formula in equation 2 . So that:

$$
\begin{aligned}
\mathrm{V} 1 & =(0,25 * 0,6667)+(0,2 * 1)+(0,15 * 0,6667)+(0,1 * 0,5)+(0,1 * 1)+(0.1 * 0,5)+(0,1 * 1)=0,77 \\
\mathrm{~V} 2 & =(0,25 * 0,3333)+(0,2 * 0,5)+(0,15 * 0,3333)+(0,1 * 1)+(0,1 * 0,5)+(0.1 * 1)+(0,1 * 1)=0,5833 \\
\mathrm{~V} 3 & =(0,25 * 1)+(0,2 * 1)+(0,15 * 1)+(0,1 * 1)+(0,1 * 0,5)+(0.1 * 0,5)+(0,1 * 0,5)=0,85 \\
\mathrm{~V} 4 & =((0,25 * 1)+(0,2 * 1)+(0,15 * 1)+(0,1 * 0,5)+(0,1 * 0,5)+(0.1 * 1)+(0,1 * 0,5)=0,85 \\
\text { V5 } & =(0,25 * 0,6667)+(0,2 * 1)+(0,15 * 1)+(0,1 * 1)+(0,1 * 0,5)+(0.1 * 0,5)+(0,1 * 1)=0,8167
\end{aligned}
$$

From the calculation of Vi values from each house that will get home rehabilitation assistance, a table of ranking determination can be made as follows:

Table 11. Determination of ranking

\begin{tabular}{llll}
\hline No & Name & Value & Rank \\
\hline 1 & Kaka 3 & 0,85 & 1 \\
2 & Kaka 4 & 0,85 & 2 \\
3 & Kaka 5 & 0,8167 & 3 \\
4 & Kaka 1 & 0,77 & 4 \\
5 & Kaka 2 & 0,5833 & 5 \\
\hline
\end{tabular}

From the results of the calculation above it can be concluded that the determination of acceptance of assistance using the SAW method was selected the largest value, namely for alternatives V3 and V4 as the best alternative.

\subsection{System Design}

The following is the design of a decision support system for determining housing rehabilitation assistance

a) Designing Data Flow Diagrams (DFD)

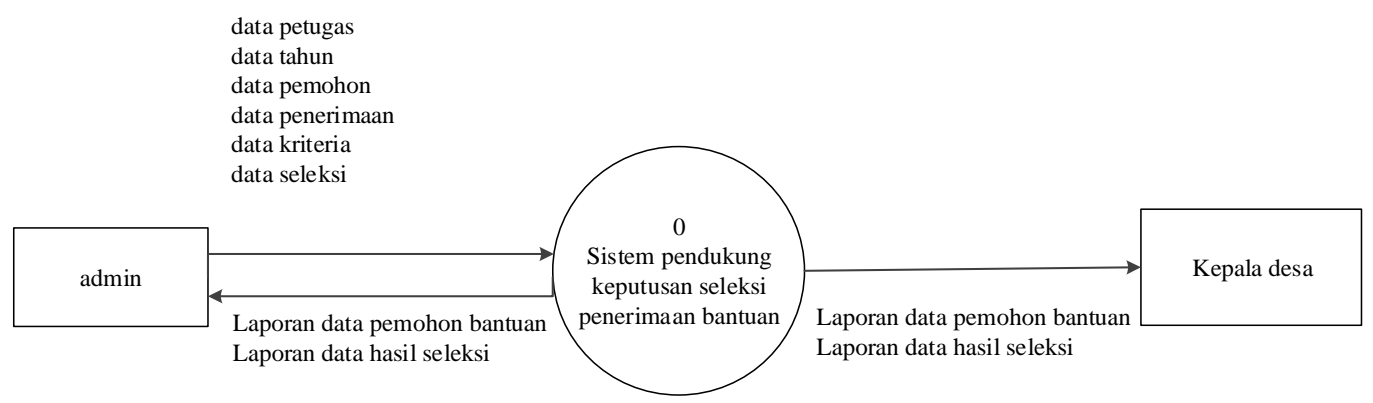

Figure 1. DFD Level 0

Figure 1 shows DFD Level 0 with the following process:

1) In all processes the admin is responsible for the data input process and the transaction process that is running. 
2) When the transaction data has been stored in the system database, the applicant's data report will result in assistance with rehabilitation of uninhabitable homes and the results of the selection based on the calculations that can be accessed by the admin itself and the village head which can be used as evaluation and policy determination.

3) The village head in the system is the control of the current transaction process, not inputting data or the selection process for providing assistance for rehabilitation of uninhabitable homes to the applicants.

b) Database design

The following is the database design using relationships between tables. Table relationships are relationships between tables that are interconnected with other tables. Table relationship design makes it easy for users to know the flow of the system to be worked on. The design of the system table support for the selection decision for receiving non-habitable house rehabilitation assistance can be seen in Figure 2.

c) Design system

1) Login Design

Login Form is a form to enter the application process by using access rights. The login form for the system application supporting the selection decision for receiving non-habitable house rehabilitation assistance can be seen in Figure 3.

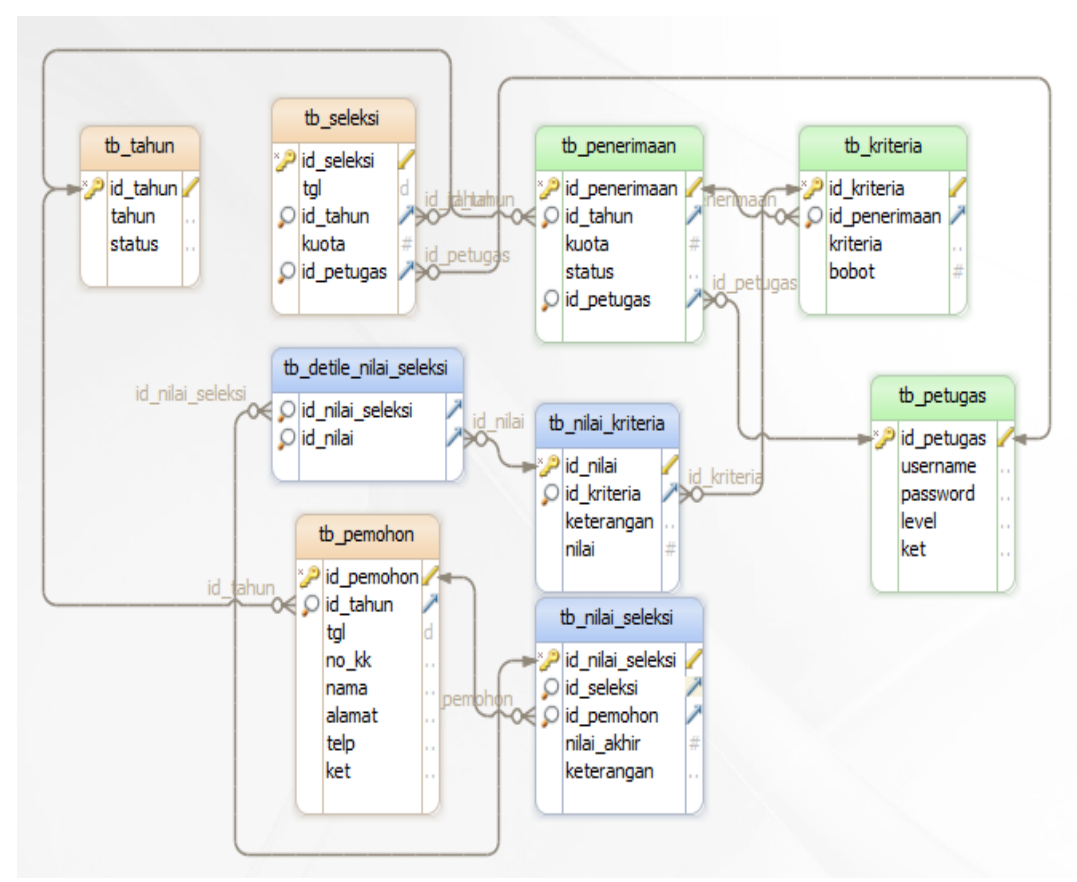

Figure 2. Database Design

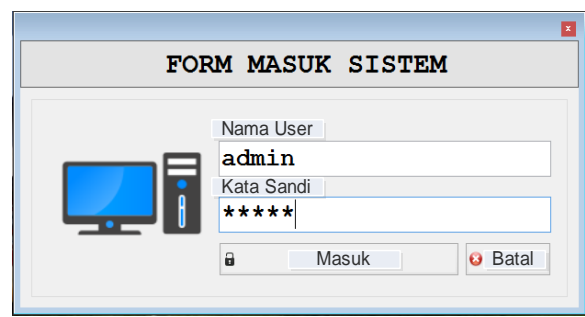

Figure 3. Login Form 


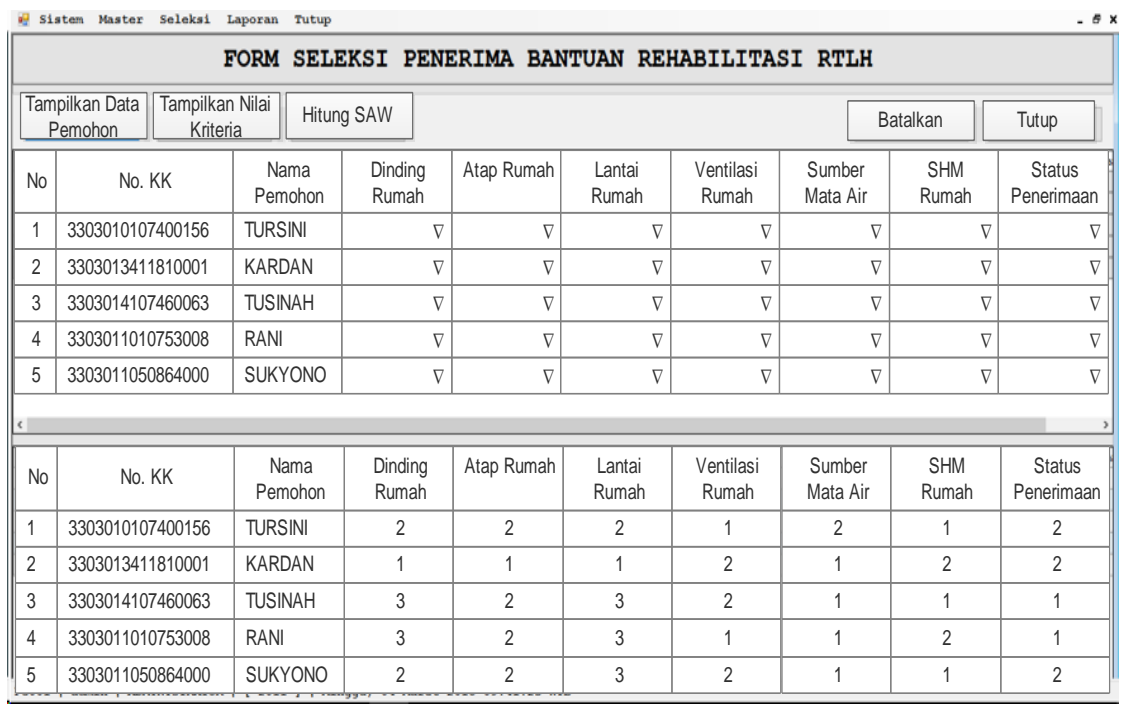

Figure 4. Draft Criteria Value

2) Draft of Criteria Value

The selection form for receiving assistance is a form used to select applicants for assistance in accordance with the criteria in the field. The selection form for receiving assistance can be seen in Figure 4.

3) Draft of Final Value Output

The applicant's year data report form is a form used to display the results of the year of receipt of data. The form of report data from the selection of assistance can be seen in Figure 5.

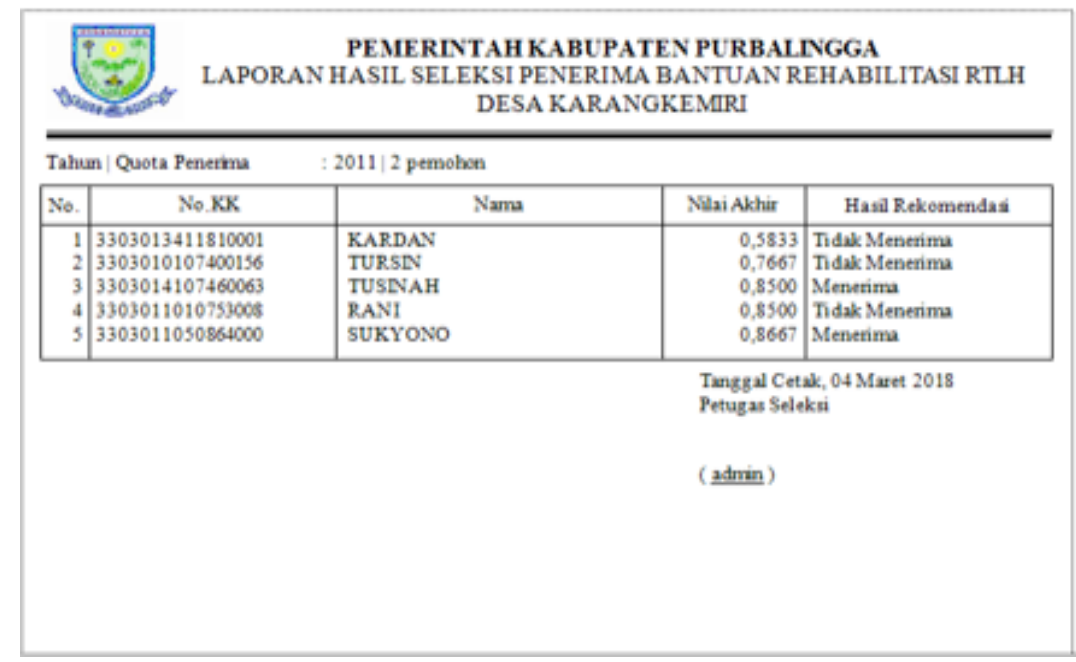

Figure 5. Draft of Final Value Output

\section{CONCLUSSION}

Based on the results of the research that has been done, it can be concluded that the Decision Support System with the Simple Additive Weighting (SAW) method for selecting the recipient of funds to rehabilitate homes that are considered unfit for poor families has been successfully built. The end result in the form of recommendations in the process of selecting the recipients of assistance for rehabilitating uninhabitable homes and determining the feasibility and failure of potential beneficiaries. The conclusion obtained is that the application has been made in accordance with what is needed by the user and this application can be applied in the village of Karangkemiri. However, the author realizes that this application still has many disadvantages.

Therefore, for a better decision support system, suggestions for the next research are as follows: Selection decision system for recipients of uninhabitable housing rehabilitation can be further developed with other decision-making methods so that they can show similarities or differences in results; This 
application can be more developed into a web or android application because applications that are made are still desktop based.

\section{REFERENCE}

[1] Pemerintah Daerah Kabupaten Purbalingga, "Peraturan Bupati Purbalingga Nomor 13 Tahun 2017 Tentang Pedoman Umum Bantuan Sosial Kegiatan Rehabilitasi Rumah Tidak Layak Huni Di Kabupaten Purbalingga Tahun 2017," Purbalingga, 2017.

[2] H. Wibowo S, "MADM-TOOL: Aplikasi Uji Sensitivitas Untuk Model Madm Menggunakan Metode Saw Dan Topsis," in Seminar Nasional Aplikasi Teknologi Informasi, 2010, p. E-56-E61.

[3] Berlilana, F. D. Prayoga, and F. S. Utomo, "Implementasi Simple Additive Weighting Dan Weighted Product pada Sistem Pendukung Keputusan untuk Rekomendasi Penerima Beras Sejahtera," J. Teknol. Inf. dan Ilmu Komput., vol. 5, no. 4, pp. 419-426, 2018.

[4] J. A. janet L. Batu and C. Fibriani, "Analisis Penentuan Lokasi Evakuasi Bencana Banjir dengan Pemanfaatan Sistem Informasi Geografis dan Metode Simple Additive Weighting," J. Teknol. Inf. dan Ilmu Komput., vol. 4, no. 2, pp. 127-135, 2017.

[5] N. K. Sukerti, "Sistem Penunjang Keputusan Penerima Bantuan Desa di Kecamatan Klungkung dengan Metode SAW," J. Inform., vol. 14, no. 1, pp. 84-93, 2014.

[6] M. D. Cahyo and Berlilana, "Sistem Pendukung Keputusan untuk Menyeleksi Calon Penerima Subsidi Beras Masyarakat Miskin (Raskin) Menggunakan Metode Simple Additive Weighting (Saw) Berbasis Web," STMIK Amikom Purwokerto, 2017.

[7] S. Eniyati, "Perancangan Sistem Pendukung Pengambilan Keputusan untuk Penerimaan Beasiswa dengan Metode SAW ( Simple Additive Weighting ),” J. Teknol. Inf. Din., vol. 16, no. 2, pp. 171177, 2011.

[8] R. Nasriyah, Z. Arham, and Q. Aini, "Profile Matching and Competency Based Human Resources Management Approaches for Employee Placement Decision Support System (Case Study)," Asian J. Appl. Sci., vol. 9, no. 2, pp. 75-86, 2016.

[9] A. E. M. Al-juaidi, "Decision support system analysis with the graph model on non-cooperative generic water resource conflicts,” Int. J. Eng. Technol., vol. 6, no. 4, pp. 145-153, 2017.

[10] J. Shang, P. R. Tadikamalla, L. J. Kirsch, and L. Brown, "A decision support system for managing inventory at GlaxoSmithKline,” Decis. Support Syst., vol. 46, no. 1, pp. 1-13, 2008.

[11] R. Rahim, A. S. Ahmar, A. P. Ardyanti, and D. Nofriansyah, "Visual Approach of Searching Process using Boyer-Moore Algorithm,” J. Phys. Conf. Ser., vol. 930, no. 1, p. 12001, 2017.

[12] R. Rahim, I. Zulkarnain, and H. Jaya, "A review: search visualization with Knuth Morris Pratt algorithm,” IOP Conf. Ser. Mater. Sci. Eng., vol. 237, no. 1, p. 12026, 2017.

[13] R. Ratnadewi, E. M. Sartika, R. Rahim, B. Anwar, M. Syahril, and H. Winata, "Crossing Rivers Problem Solution with Breadth-First Search Approach," IOP Conf. Ser. Mater. Sci. Eng., vol. 288, no. 1, p. $12125,2018$.

[14] F. Haswan, "Decision Support System For Election Of Members Unit Patients Pamong Praja," Int. J. Artif. Intelegence Res., vol. 1, no. 1, pp. 21-25, 2017.

[15] A. Solomon, N. Wishart, and S. Dublish, "Multi-attribute decision making: A simulation comparison of select methods," Eur. J. Oper. Res., vol. 107, no. 3, pp. 507-529, 1998.

[16] I. C. Ishak et al., "Sistem Pendukung Keputusan Kelayakan Sertifikasi Guru Menggunakan Metode Simple Additive Weighting ( SAW )," E-Journal Tek. Inform., vol. 10, no. 1, pp. 1-10, 2017. 